\title{
PENGGUNAAN ENZIM RENNET DAN BAKTERI Lactobacillus plantarum YN 1.3 TERHADAP SIFAT SENSORIS KEJU
}

\author{
Truly M. Hutagalung, A. Yelnetty*, M. Tamasoleng, J. H. W. Ponto
}

Fakultas Peternakan Universitas Sam Ratulangi Manado, 95115

\begin{abstract}
ABSTRAK
Penelitian ini bertujuan untuk mengetahui penggunaan enzim rennet dan bakteri Lactobacillus plantarum YN 1.3 terhadap sifat sensoris keju. Rancangan penelitian yang digunakan adalah Rancangan Acak Lengkap (RAL) dengan perlakuan level rennet 10\%, 8\%, 6\%, 4\%, $2 \%$ dan bakteri Lactobacillus plantarum YN $1.30 \%, 2 \%, 4 \%, 6 \%, 8 \%$, dimana masing-masing perlakuan diulang sebanyak empat puluh (panelis) dengan memakai skala hedonik. Hasil penelitian menunjukkan bahwa penggunaan enzim rennet dan bakteri Lactobacillus plantarum YN 1.3 memberikan pengaruh berbeda sangat nyata $(\mathrm{P}<0,01)$ terhadap warna, aroma, tekstur dan citarasa keju. Berdasarkan hasil analisa data dan pembahasan dalam penelitian ini disimpulkan bahwa keju dengan perlakuan Enzim rennet 2\% dan bakteri Latobacillus plantarum $Y N \quad 1.38 \%$ pada pengujian sensoris terhadap warna, aroma, tekstur, dan citarasa merupakan keju terbaik serta disukai oleh panelis.
\end{abstract}

Kata kunci: Keju, Enzim Rennet, Bakteri Lactobacillus plantarum YN 1.3.

\section{ABSTRACT}

THE UTILIZING OF RENNET ENZYMES and Lactobacillus plantarum YN 1.3 BACTERIA ON SENSORY CHARACTERISTICS OF CHEESE.

*Korespondensi (corresponding author)

Email: Afrizafapet@gmail.com
This research aims to determine the utilizing of rennet enzymes and Lactobacillus plantarum YN 1.3 bacteria on sensory characteristics of cheese. This experiment using a completely randomized design (CRD) with treatments level of rennet enzymes $10 \%, 8 \%, 6 \%, 4 \%, 2 \%$ and Lactobacillus plantarum YN 1.3 bacteria on $0 \%, 2 \%, 4 \%, 6 \%, 8 \%$ levels, which is each treatment repeated as much as 40 of replications (panelists) with hedonic method used. The result showed that the utilizing of rennet enzyme and Lactobacillus plantarum YN 1.3 bacteria gives highly signifant different effects $(\mathrm{P}<0,01)$ on cheese color, aroma, texture and flavor. Based on the results of data analysis and discussions, can be concluded that cheese with rennet enzyme $2 \%$ and Lactobacillus plantarum YN 1.3 bacteria $8 \%$, is the best performs and most preferred to panelists.

Key words: Cheese, Rennet Enzyme, Lactobacillus plantarum YN 1.3.

\section{PENDAHULUAN}

Keju merupakan gumpalan atau substansi yang dibentuk karena koagulasi protein susu dari ternak ruminansia, oleh reaksi enzim rennin atau enzim proteolitik lainnya, dalam kondisi asam oleh adanya asam laktat hasil kerja dari bakteri asam laktat yang ditambahkan. Penggunaan enzim rennet umumnya diperoleh dari 
lambung anak sapi yang masih menyusui pada induknya, dimana ketersediaannya semakin terbatas sehingga perlu disiasati dengan melihat potensi ternak ruminansia lain, salah satunya adalah ternak kambing.

Rennet merupakan penggumpal kasein pada proses pembuatan keju yang di dalamnya mengandung enzim protease rennin. Enzim rennet yang digunakan merupakan enzim yang bersifat proteolitik yang dapat menggumpalkan susu pada proses awal pembuatan keju. Bakteri asam laktat yang sering digunakan pada industri keju adalah jenis Lactobacillus lactis.

\section{Bakteri Lactobacillus plantarum}

YN 1.3 adalah bakteri yang diisolasi dari susu kambing secara spontan, mempunyai sifat proteolitik, mempunyai kemampuan memfermentasi laktosa yang dapat menurunkan $\mathrm{pH}$ susu selama proses fermentasi berlangsung dan dapat sebagai starter komersial pada industri. Bakteri ini dapat digunakan dalam pembuatan yoghurt dan hasilnya sangat baik.

Penilaian sifat sensoris berperan penting dalam menentukan produk keju yang dihasilkan, yang meliputi penilaian warna, aroma, tekstur dan citarasa. Berdasarkan uraian diatas maka dilakukan penelitian yang bertujuan untuk mengetahui sifat sensoris keju yang menggunakan enzim rennet dari abomasum kambing dan bakteri asam laktat jenis Lactobacillus plantarum YN 1.3.

\section{MATERI DAN METODE PENELITIAN}

Penelitian ini telah dilaksanakan pada tanggal 28 November 2016 sampai dengan 24 Januari 2017 di Laboratorium Teknologi Hasil Ternak, Fakultas Peternakan Universitas Sam Ratulangi Manado. Bahan bahan yang digunakan adalah: 20 liter susu sapi segar yang diambil dari Balai Pengembangan Bibit dan Pakan Ternak di Desa Tampusu, Enzim rennet, Bakteri asam laktat (Lactobacillus plantarum YN 1.3).

Bahan analisa yang digunakan adalah media MRSB (de Man-RogosaSharpe Broth), alkohol 70\%, aquadest, spritus dan bahan-bahan lain yang digunakan untuk sensoris antara lain air mineral dan ketimun. Peralatan yang digunakan selama penelitian antara lain, lemari pendingin, timbangan digital, kompor, autoclave, erlenmeyer, tabung reaksi, inkubator, thermometer, karet, kapas, pisau, telenan, tusuk gigi, stirer, dan centrifuge.

Rancangan penelitian yang digunakan dalam penelitian ini adalah Rancangan Acak Lengkap (RAL) dengan perlakuan level rennet 10\%, $8 \%, 6 \%, 4 \%$, $2 \%$ dan Bakteri Lactobacillus plantarum YN $1.30 \%, 2 \%, 4 \%, 6 \%, 8 \%$. masingmasing perlakuan diulang sebanyak empat puluh (panelis). Data yang diperoleh 
dianalisis menggunakan analisis varians, kemudian dilanjutkan dengan uji beda nyata jujur (BNJ) (Steel dan Torrie, 1991). Level enzim rennet dan level bakteri Lactobaillus plantarum YN 1.3 yang digunakan adalah:

A0: Enzim rennet $10 \%+$ bakteri Lactobacillus plantarum YN $1.30 \%$

A1: Enzim rennet $8 \%+$ bakteri Lactobacillus plantarum YN $1.32 \%$

A2: Enzim rennet $6 \%+$ bakteri Lactobacillus plantarum YN $1.34 \%$

A3: Enzim rennet $4 \%+$ bakteri Lactobacillus plantarum YN $1.36 \%$

A4: Enzim rennet $2 \%+$ bakteri Lactobacillus plantarum YN $1.38 \%$.

Variabel yang dianalisis pada penelitian ini adalah sifat sensoris atau organoleptic meliputi warna, aroma, tekstur dan citarasa.

\section{HASIL DAN PEMBAHASAN}

\section{Pengaruh Perlakuan Terhadap Sifat Sensoris (Organoleptik) Keju}

Uji sensoris atau organoleptik terhadap suatu bahan pangan merupakan indikator yang dapat menunjukkan tingkat penerimaan konsumen terhadap produk tersebut. Pengaruh perlakuan terhadap sifat sensoris (organoleptik) keju yan diamati dalam penelitian ini meliputi warna, aroma, tekstur dan citarasa.

\section{Warna Keju}

Warna merupakan salah satu parameter yang diukur dalam penilaian mutu dan tingkat penerimaan panelis atas sebuah produk. Data pada Tabel 1 diketahui bahwa perlakuan yang diberikan berupa level rennet dan bakteri Lactobacillus plantarum YN 1.3 menunjukkan bahwa tingkat kesukaan panelis terhadap warna keju berkisar antara 4,60 (Agak suka) sampai 5,88 (suka). Nilai rataan skor tertinggi diperoleh pada perlakuan A4 yakni enzim rennet $2 \%$ dan bakteri Lactobacillus plantarum YN $1.38 \%$ dan terendah pada perlakuan $\mathrm{A} 0$ enzim rennet $10 \%$ dan bakteri Lactobacillus plantarum YN $1.30 \%$.

Hasil analisis sidik ragam menunjukkan bahwa perlakuan enzim rennet dan bakteri Lactobacillus plantarum YN 1.3 memberikan pengaruh yang berbeda sangat nyata $(\mathrm{P}<0,01)$ terhadap warna keju yang dihasilkan. Berdasarkan hasil uji lanjut dengan uji beda nyata jujur menunjukkan bahwa perlakuan A0 berbeda sangat nyata $(\mathrm{P}<0,01)$ dengan $\mathrm{A} 1, \mathrm{~A} 2, \mathrm{~A} 3$ dan A4. dan perlakuan A1 berbeda tidak nyata $(\mathrm{P}<0,01)$ dengan $\mathrm{A} 2$ dan $\mathrm{A} 3$ tapi $\mathrm{A} 1$ berbeda sangat nyata $(\mathrm{P}<0,01)$ dengan $\mathrm{A} 0$ dan A4. Perlakuan A2 berbeda tidak nyata $(\mathrm{P}<0,01)$ dengan $\mathrm{A} 1$ dan $\mathrm{A} 3$, tapi $\mathrm{A} 2$ berbeda sangat nyata $(\mathrm{P}<0,01)$ dengan $\mathrm{A} 0$ dan A4. Perlakuan A3 berbeda tidak nyata 
Tabel 1. Rataan Pengaruh Perlakuan Terhadap Sifat Sensoris Keju

\begin{tabular}{cccccc}
\hline \multirow{2}{*}{ Variabel } & \multicolumn{5}{c}{ Perlakuan Enzim Rennet Dan Bakteri Lactobacillus plantarum YN 1.3 } \\
\cline { 2 - 6 } & $\mathrm{A} 0$ & $\mathrm{~A} 1$ & $\mathrm{~A} 2$ & $\mathrm{~A} 3$ & $\mathrm{~A} 4$ \\
\hline Warna & $4,60^{\mathrm{a}}$ & $5,23^{\mathrm{b}}$ & $5,28^{\mathrm{bc}}$ & $5,35^{\mathrm{bcd}}$ & $5,88^{\mathrm{e}}$ \\
Aroma & $4,55^{\mathrm{a}}$ & $5,45^{\mathrm{b}}$ & $5,55^{\mathrm{bc}}$ & $5,60^{\mathrm{bcd}}$ & $6,03^{\mathrm{e}}$ \\
Tekstur & $4,48^{\mathrm{a}}$ & $5,00^{\mathrm{b}}$ & $5,05^{\mathrm{bc}}$ & $5,33^{\mathrm{cd}}$ & $5,50^{\mathrm{de}}$ \\
Citarasa & $4,68^{\mathrm{a}}$ & $5,05^{\mathrm{b}}$ & $5,13^{\mathrm{bc}}$ & $5,25^{\mathrm{bcd}}$ & $5,65^{\mathrm{e}}$ \\
\hline
\end{tabular}

Keterangan : Superskrip yang berbeda pada baris yang sama artinya berbeda sangat nyata $(\mathrm{P}<0,01)$.

$(\mathrm{P}<0,01)$ dengan $\mathrm{A} 1$ dan $\mathrm{A} 2$ tapi A3 berbeda sangat nyata $(\mathrm{P}<0,01)$ dengan $\mathrm{A} 0$ dan A4. Sedangkan Perlakuan A4 berbeda sangat nyata $(\mathrm{P}<0,01)$ dengan $\mathrm{A} 0, \mathrm{~A} 1, \mathrm{~A} 2$, dan A3.

Data hasil uji sensoris warna keju perlakuan A4 yakni enzim rennet $2 \%$ dan bakteri Lactobacillus plantarum YN $1.38 \%$ lebih disukai panelis, hal ini disebabkan karena warna keju yang di hasilkan lebih kuning dibandingkan dengan perlakuan lainnya. Hal ini selain di pengaruhi oleh susu yang digunakan, warna keju juga dipengaruhi oleh adanya penambahan bakteri Lactobacillus plantarum YN 1.3. Menurut (Buckle et al., 1987) Keju yang dibuat dari susu sapi tanpa pewarna akan menghasilkan keju yang berwarna putih kekuning-kuningan karena adanya pigmen karoten yang larut didalam lemak susu. Sejalan dengan pendapat (Rahman et al., 1992) juga menyatakan bahwa bakteri asam laktat mempunyai kemampuan dalam penguraian lemak, protein, zat-zat organik dan akan memberikan pengaruh terhadap karakteristik fisik dan kimia keju yang dihasilkan.

\section{Aroma Keju}

Data pada Tabel 1, diketahui bahwa perlakuan yang diberikan berupa level rennet dan bakteri Lactobacillus plantarum YN 1.3 yang digunakan menghasilkan aroma yang khas dan sangat berpengaruh terhadap aroma keju yang dihasilkan. Tingkat kesukaaan panelis terhadap aroma keju berkisar antara 4,55 (agak suka) sampai 6,03 (suka). Nilai rataan skor tertinggi diperoleh pada perlakuan A4 yakni enzim rennet $2 \%$ dan bakteri Lactobacillus plantarum YN $1.3 \quad 8 \%$, sedangkan terendah pada perlakuan A0 yakni enzim rennet $10 \%$ dan bakteri Lactobacillus plantarum YN $1.3 \quad 0 \%$. Berdasarkan nilai aroma keju, panelis lebih menyukai aroma keju dengan perlakuan A4 yakni enzim rennet $2 \%$ dan bakteri Lactobacillus plantarum YN $1.38 \%$ dengan 
skor 6,03 yang termasuk dalam kategori suka. Berdasarkan hasil analisis sidik ragam menunjukkan bahwa perlakuan level enzim rennet dan bakteri Lactobacillus plantarum YN 1.3 yang berbeda memberikan pengaruh yang berbeda sangat nyata $(\mathrm{P}<0,01)$ terhadap tingkat kesukaan aroma keju yang dihasilkan.

Hasil uji lanjut dengan Uji Beda Nyata Jujur menunjukkan bahwa perlakuan A0 berbeda sangat nyata $(\mathrm{P}<0,01)$ dengan A1, A2, A3 dan A4. Dan perlakuan A1 berbeda tidak nyata $(\mathrm{P}<0,01)$ dengan $\mathrm{A} 2$ dan A3 tapi A1 berbeda sangat nyata $(\mathrm{P}<0,01)$ dengan A0 dan A4. Perlakuan A2 berbeda tidak nyata $(\mathrm{P}<0,01)$ dengan $\mathrm{A} 1$ dan A3 tapi A2 berbeda sangat nyata $(\mathrm{P}<0,01)$ dengan A0 dan A4. Perlakuan A3 berbeda tidak nyata $(\mathrm{P}<0,01)$ dengan $\mathrm{A} 1$ dan A2 tapi A3 berbeda sangat nyata $(\mathrm{P}<0,01)$ dengan A0 dan A4. Sedangkan perlakuan A4 berbeda sangat nyata $(\mathrm{P}<0,01)$ dengan A0, A1, A2 dan A3.

Berdasarkan hasil uji sensoris, semua keju menghasilkan aroma yang khas hal ini dipengaruhi oleh penambahan bakteri Lactobacillus plantarum YN 1.3. Menurut (Singh, 2003) Peranan utama bakteri dalam fermentasi keju yaitu untuk memulai fermentasi dengan produksi asam dari proses metabolismenya, menyebabkan koagulasi protein yang dapat menghambat pertumbuhan bakteri pathogen. Produksi asam laktat dapat menimbulkan aroma khas pada keju dan juga dapat mempengaruhi pembentukan tekstur selama pembentukan curd. Yelnetty et al. (2014) menyatakan bahwa bakteri Lactobacillus plantarum YN 1.3 selain menghasilkan asam laktat juga menghasilkan asam asetat, butirat dan propionat. Asam-asam ini akan mempengaruhi rasa pada keju yang dihasilkan. Hasil skor untuk aroma keju yang terbaik diperoleh pada perlakuan A4 yakni enzim rennet $2 \%$ dan bakteri Lactobacillus plantarum YN 1.3 dengan skor 6,03 (suka).

\section{Tekstur Keju}

Data pada Tabel 1 menunjukkan bahwa perlakuan yang diberikan berupa penambahan level enzim rennet dan bakteri $\begin{array}{llll}\text { Lactobacillus } & \text { plantarum } \quad Y N & 1.3\end{array}$ berpengaruh terhadap tekstur keju yang dihasilkan. Hasil yang diperoleh menunjukkan bahwa tingkat kesukaan panelis terhadap tekstur keju dengan perlakuan yang berbeda, berkisar antara 4,48 (netral) sampai 5,50 (agak suka). Nilai rataan skor tertinggi terdapat pada perlakuan A4 yakni enzim rennet $2 \%$ dan bakteri Lactobacillus plantarum YN 1.3 $8 \%$. Sedangkan terendah pada perlakuan A0 enzim rennet $10 \%$ dan bakteri Lactobacillus plantarum YN $1.30 \%$. 
Berdasarkan hasil analisis sidik ragam menunjukkan bahwa perlakuan enzim rennet dan bakteri Lactobacillus plantarum $Y N 1.3$ memberikan pengaruh yang berbeda sangat nyata $(\mathrm{P}<0,01)$ terhadap tekstur keju yang dihasilkan. Setelah dilanjutkan dengan uji beda nyata jujur menunjukkan bahwa perlakuan A0 berbeda sangat nyata $(\mathrm{P}<0,01)$ dengan $\mathrm{A} 1$, A2, A3 dan A4. Dan perlakuan A1 berbeda tidak nyata $(\mathrm{P}<0,01)$ dengan $\mathrm{A} 2$ tapi $\mathrm{A} 1$ berbeda sangat nyata $(\mathrm{P}<0,01)$ dengan $\mathrm{A} 0$, A3 dan A4. Dan perlakuan A2 berbeda tidak nyata $(\mathrm{P}<0,01)$ dengan $\mathrm{A} 1$ dan $\mathrm{A} 3$ tapi A2 berbeda sangat nyata $(\mathrm{P}<0,01)$ dengan perlakuan A0 dan A4. Perlakuan A3 berbeda tidak nyata $(\mathrm{P}<0,01)$ dengan $\mathrm{A} 2$ dan A4 tapi A3 berbeda sangat nyata $(\mathrm{P}<0,01)$ dengan $\mathrm{A} 0$ dan $\mathrm{A} 1$. Sedangkan perlakuan A4 berbeda tidak nyata $(\mathrm{P}<0,01)$ dengan A3 tapi perlakuan A4 berbeda sangat nyata $(\mathrm{P}<0,01)$ dengan $\mathrm{A} 0, \mathrm{~A} 1$ dan A2.

Berdasarkan hasil uji sensoris, perlakuan keju menghasilkan tekstur yang disukai oleh panelis hal ini mungkin dikarenakan perlakuan level enzim rennet dan bakteri asam laktat yang digunakan berpengaruh terhadap tekstur keju yang dihasilkan. Sejalan dengan hal diatas, Hidayat et al. (2006) menyatakan bahwa penambahan kultur bakteri biasanya bakteri asam laktat akan membantu proses pembentukan curd dan juga menentukan tekstur dari keju. Menurut Yelnetty et al. (2014) bahwa bakteri Lactobacillus plantarum YN 1.3 merupakan bakteri yang bersifat proteolitik yang mempunyai kemampuan dalam pembentukan curd. Perubahan hidrolitik yang disebabkan oleh sifat proteolitik enzim rennet tidak hanya penting dalam pengembangan flavor tetapi juga berpengaruh terhadap tekstur keju (Tarakci dan Kucukoner, 2006). Hasil skor untuk tekstur keju yang terbaik diperoleh pada perlakuan A4 dengan skor 5,50 (suka).

\section{Citarasa Keju}

Citarasa merupakan faktor terpenting terhadap akseptabilitas selain warna, aroma dan tekstur. Berdasarkan Tabel 1, diketahui bahwa perlakuan yang diberikan berupa level enzim rennet dan bakteri Lactobacillus plantarum YN 1.3 dengan level yang berbeda menunjukkan bahwa tingkat kesukaan panelis terhadap citarasa keju dengan perlakuan yang berbeda berkisar antara 4.68 (agak suka) sampai 5.65 (suka).

Berdasarkan hasil analisis sidik ragam menunjukkan bahwa perlakuan enzim rennet dan bakteri Lactobacillus plantarum $Y N 1.3$ memberikan pengaruh sangat nyata $(\mathrm{P}<0.01)$ terhadap citarasa keju. Berdasarkan hasil uji lanjut dengan uji beda nyata jujur menunjukkan bahwa perlakuan A0 berbeda sangat nyata $(\mathrm{P}<0,01)$ dengan perlakuan $\mathrm{A} 1, \mathrm{~A} 2, \mathrm{~A} 3$ dan 
A4. Perlakuan A1 berbeda tidak nyata $(\mathrm{P}<0,01)$ dengan perlakuan $\mathrm{A} 2$ dan $\mathrm{A} 3$ tapi A1 berbeda sangat nyata $(\mathrm{P}<0,01)$ dengan perlakuan A0 dan A4. Dan perlakuan A2 berbeda tidak nyata $(\mathrm{P}<0,01)$ dengan $\mathrm{A} 1$ dan A3 tapi A2 berbeda sangat nyata $(\mathrm{P}<0,01)$ dengan A0 dan A4. Perlakuan A3 berbeda tidak nyata $(\mathrm{P}<0,01)$ dengan $\mathrm{A} 1$ dan A2 tapi A3 berbeda sangat nyata $(\mathrm{P}<0,01)$ dengan A0 dan A4. Sedangkan perlakuan A4 berbeda sangat nyata $(\mathrm{P}<0,01)$ dengan A0, A1, A2 dan A3. Datadata tersebut menunjukkan bahwa panelis lebih menyukai keju dengan perlakuan A4 yakni enzim rennet $2 \%$ dan bakteri Lactobacillus plantarum YN $1.38 \%$ hal ini dipengaruhi oleh perlakuan yang diberikan. Broadbent et al. (2003) menyatakan bahwa penambahan starter memberikan flavor atau rasa yang khas pada keju yang dihasilkan. Aktifitas starter yang digunakan akan menguraikan laktosa menjadi asam laktat sehingga akan menghasilkan rasa yang khas. Selain starter, rennet juga berperan dalam pengembangan flavor keju dan sebagai koagulan terhadap proteolisis primer yaitu pemecahan protein menjadi peptida - peptida (Hayaloglu et al., 2007). Berdasarkan skala tingkat kesukaan diketahui bahwa panelis bisa menerima semua perlakuan level rennet dan bakteri Lactobacillus plantarum YN 1.3. Nilai skor yang terbaik terdapat pada perlakuan A4 yakni enzim rennet $2 \%$ dan Bakteri Lactobacillus plantarum YN $1.38 \%$.

\section{KESIMPULAN}

Berdasarkan hasil analisa data dan pembahasan dalam penelitian ini disimpulkan bahwa keju dengan perlakuan Enzim rennet $2 \%$ dan bakteri Latobacillus plantarum YN $1.38 \%$ pada pengujian sensoris terhadap warna, aroma, tekstur, dan citarasa merupakan keju terbaik serta disukai oleh panelis.

\section{DAFTAR PUSTAKA}

Broadbent, J.R., K. Houck, M.E. Johnson, and C.J. Oberg. 2003. Influence of adjunt use and cheese microenvironment on non starter bacteria in reduced fat cheedar type cheese. Journal Dairy Sci. 86: 27732782

Buckle, K.A, R.A. Edwads, G.H. Fleet. 1987. Ilmu Pangan. Penerbit Universitas Indonesia. Jakarta.

Hayaloglu, A. A., S. Cakmakci, E. Y. Brechany, K. C. Deegan and P. L. H. 2007. Microbiology, Biochemistry and Volatile Composition of Tulum Cheese Ripened in Goat's Skin or Plastic Bags. Journal Dairy Sci. 90: 1102-1121.

Hidayat, N., M.C. Padaga dan S. Suhartini. 2006. Mikrobiologi Industri. CV Andi Offset, Yogyakarta.

Rahman, A., S. Fardiaz, W.P. Rahayu dan C.C. Nurwitri. 1992. Teknologi 
fermentasi susu. Departemen Pendidikan dan Kebudayaan Direktorat Jendral Pendidikan Tinggi Pusat Antar Universitas Pangan dan Gizi Insitut Pertanian Bogor.

Singh, T. K., M. Drake, and Cadwallader. 2003. Flavor of cheddar cheese, chemical and sensory perspective. Comprehensive reviews in Journal Food Science and Food Safety 2: 139-162.

Steel, R.G.D dan J.H. Torrie. 1991. Prinsip dan Prosedur Statistika. Gramedia Pustaka Utama, Jakarta
Tarakci, Z. dan E. Kucukoner. 2006. Changes on physicochemical, lipolysis and proteolysis of vacuumpacked turkish kashar cheese during ripening. Journal Central Euro. Agric. 7 (3): 459-464.

Yelnetty, A., Purnomo H., Purwadi, A. Mira. 2014. Biochemical characteristics of lactic acid bakteria with proteolytic activity and capability as starter culture. Isolated from spontaneous fermented local goat milk. Journal of Natural Sciences Research. Vol, 4 (10): 147-155. 